\title{
HUBUNGAN GAYA HIDUP DAN POLA MAKAN DENGAN KEJADIAN HIPERTENSI PADA LANSIA DI KELURAHAN SAWANGAN BARU KOTA DEPOK TAHUN 2015
}

\section{THECORRELATION OF LIFE STYLE AND DIETARY HABIT WITH HYPERTENSION IN THE ELDERLY AT SAWANGAN BARU, DEPOK, 2015}

\author{
Solehatul Mahmudah, Taufik Maryusman, Firlia Ayu Arini, dan Ibnu Malkan \\ Program Studi S1 Ilmu Gizi, Fakultas Ilmu Kesehatan, Universitas Pembangunan Nasional \\ "Veteran" Jakarta
}

Korespondensi: Taufik Maryusman, Email: jtaufi@gmail.com

\begin{abstract}
ABSTRAK
Beberapa faktor resiko diduga memiliki peran dalam terjadinya hipertensi seperti gaya hidup, pola makan dan usia. Hipertensi merupakan salah satu faktor resiko penyebab terjadinya penyakit kardiovaskuler. Penelitian ini bertujuan untuk mengetahui hubungan gaya hidup dan pola makan dengan kejadian hipertensi pada lansia. Penelitian cross sectional ini diikuti oleh 74 responden dengan cara purposive sampling. Hasil penelitian ini mendapatkan proporsi lansia yang mengalami hipertensi sebesar 26,4\%. Analisis bivariat menggunakan uji chisquare dan analisis multivariat dengan regresi logistik ganda. Hasil analisis bivariat menunjukkan ada hubungan antara aktivitas fisik $(p=0,024$ OR=3,596), asupan lemak $(p=0,008$ OR=4,364), dan asupan natrium $(p=0,001$ $O R=6,103)$ dengan kejadian hipertensi. Analisis multivariat menunjukkan asupan natrium $(O R \operatorname{Exp}(B)=4,627)$ sebagai faktor resiko yang paling berhubungan dengan kejadian hipertensi.
\end{abstract}

Kata Kunci: Hipertensi, Gaya Hidup, Pola Makan

ABSTRACT

Some factors expected to influence the occurrence of hypertension were life style, dietary habit, and age. Hypertension was one of the factor causing cardiovascular disease. The objective of this research is to determine the correlation of life style and dietary habit with hypertension in the elderly. This cross-sectional study was followed by 74 respondents chosen by purposive sampling. The results of this research showed that the proportion of elderly people who have hypertension are about 26,4\%. The data were analyzed by bivariate analysis with chisquare test and multivariate analysis with multiple logistic regression. The results of bivariate analysis showed there is no correlation between physical activity $(p=0,024 O R=3,596)$, grease intake $(p=0,008 O R=4,364)$, and sodium intake $(p=0,001$ OR 6,103$)$ with hypertension. Multivariate analysis showed that sodium intake (OR $\operatorname{Exp}(B)=4,627)$ has the highest correlation with hypertension.

Keywords: Hypertension, Life Style, Dietary Habit

\section{PENDAHULUAN}

Lanjut usia (lansia) adalah seseorang yang mencapai usia $>60$ tahun (Indonesia. UndangUndang, 1998). Lansia rentan mengalami penyakit yang berhubungan dengan proses menua salah satunya hipertensi (Azizah, 2011).

Hipertensi identik dengan peningkatan tekanan darah melebihi batas normal (Sunardi, 2012). Seseorang dikatakan hipertensi jika hasil pengukuran tekanan darah sistoliknya $\geq 140$ $\mathrm{mmHg}$ dan diastoliknya $\geq 90 \mathrm{mmHg}$ (Hartono, 2013).
Berdasarkan data WHO dalam Noncommunicable Disease Country Profiles prevalensi didunia pada usia $>25$ tahun mencapai 38,4\%. Prevalensi Indonesia lebih besar jika dibandingkan dengan Banglandesh, Korea, Nepal, dan Thailand (Krishnan dkk. 2011). Prevalensi hipertensi di Indonesia pada usia $\geq 18$ tahun mencapai $25,8 \%$. Jawa Barat merupakan provinsi yang menempati posisi ke empat sebesar $29,4 \%$ angka ini lebih besar dibandingkan dengan prevalensi di Provinsi Jawa Tengah, Jawa Timur dan DKI Jakarta (Riset Kesehatan Dasar, 2013). 
Semakin meningkatnya usia maka lebih beresiko terhadap peningkatan tekanan darah terutama tekanan darah sistolik sedangkan diastolik meningkat hanya sampai usia 55 tahun (Nurrahmani, 2011).

Laki-laki atau perempuan sama-sama memiliki kemungkinan beresiko hipertensi. Namun, laki-laki lebih beresiko mengalami hipertensi dibandingkan perempuan saat usia $<45$ tahun tetapi saat usia $>65$ tahun perempuan lebih beresiko mengalami hipertensi (Prasetyaningrum, 2014).

Seseorang yang kedua orang tua memiliki riwayat penyakit hipertensi anaknya akan beresiko terkena hipertensi, terutama pada hipertensi primer (essensial) yang terjadi karena pengaruh genetika (Sutanto, 2010).

Gaya hidup merupakan faktor penting yang mempengaruhi kehidupan masyarakat. Gaya hidup yang tidak sehat dapat menjadi penyebab terjadinya hipertensi misalnya aktivitas fisik dan stres (Puspitorini dalam Sount dkk. 2014).

Pola makan yang salah merupakan salah satu faktor resiko yang meningkatkan penyakit hipertensi. Faktor makanan modern sebagai penyumbang utama terjadinya hipertensi (AS, 2010).

Kelebihan asupan lemak mengakibatkan kadar lemak dalam tubuh meningkat, terutama kolesterol yang menyebabkan kenaikan berat badan sehingga volume darah mengalami peningkatan tekanan yang lebih besar (Ramayulis, 2010).

Kelebihan asupan natrium akan meningkatkan ekstraseluler menyebabkan volume darah yang berdampak pada timbulnya hipertensi (Sutanto, 2010).

\section{HASIL DAN PEMBAHASAN}

Tabel 1. Distribusi Responden Menurut Kategori Tekanan Darah di Posbindu Kelurahan Sawangan Baru Kecamatan Sawangan Tahun 2015

\begin{tabular}{lcc}
\hline \multicolumn{2}{c}{ Tekanan Darah } & \multicolumn{2}{c}{ Frekuensi (n) } & Persentase (\%) \\
\hline Hipertensi & 23 & 26,4 \\
\hline Tidak Hipertensi & 64 & 73,6 \\
\hline Hasil penelitian menunjukkan bahwa & didapatkan rata-rata tekanan darah sistolik (TDS) \\
subyek pada penelitian ini lebih banyak yang & $147,47 \mathrm{mmHg}$. TDS terendah $110 \mathrm{mmHg}$ dan \\
tidak hipertensi sebanyak 64 responden $(73,6 \%)$, & tertinggi 210 mmHg. Sedangkan Rata-rata tekanan \\
sedangkan responden yang hipertensi sebanyak & darah diastolik (TDD) 82,30 mmHg. TDD terendah \\
23 responden (26,4\%). Berdasarkan hasil analisis & 56 mmHg dan TDD tertinggi 130 mmHg.
\end{tabular}

Kurangnya mengkonsumsisumbermakanan yang mengandung kalium mengakibatkan jumlah natrium menumpuk dan akan meningkatkan resiko hipertensi (Junaedi dkk. 2013).

Penelitian ini meganalisis hubungan antara gaya hidup dan pola makan dengan kejadian hipertensi pada lansia di Kelurahan Sawangan Baru Kota Depok Tahun 2015.

\section{METODE}

Penelitian ini merupakan penelitian analitik dengan pendekatan kuantitatif. Rancangan penelitian ini menggunakan cross-sectional yaitu suatu penelitian untuk mempelajari dinamika korelasi antara faktor resiko dengan efek, dengan cara pendekatan observasi atau pengumpulan data sekaligus pada suatu saat (point time approach) (Notoatmodjo, 2012). Populasi pada penelitian ini adalah lansia yang berusia $>60$ tahun yang menghadiri Posbindu di Kelurahan Sawangan Baru. Sampel pada penelitian ini sejumlah 74 responden. Besar sempel ditentukan dengan rumus (Kothari dalam Murti, 2010).

Teknik pengambilan sampel pada penelitian ini menggunakan purposive sampling. Pengumpulan data dilakukan dengan cara wawancara menggunakan kuesioner. Setelah Coding, Processing, dan Skoring selanjutnya data dianalisis secara univariat dilakukan terhadap tiap variabel, sementara analisis bivariat dilakukan dengan uji statistik chi square menggunakan program SPSS, dengan tingkat signifikan $\mathrm{p}=0,05$ (taraf kepercayaan 95\%). melalui pengolahan data yang meliputi Editing, 
Tabel 2. Gambaran Variabel Independen di Posbindu Kelurahan Sawangan Baru Kecamatan Sawangan Tahun 2015

\begin{tabular}{lcc}
\hline \multicolumn{1}{c}{ Variabel } & Frekuensi (n) & Persentase (\%) \\
\hline Usia & 64 & \\
\hline Early old age (usia 60-70 tahun) & 23 & 73,6 \\
Advancedold age (usia $>70$ tahun) & & 26,4 \\
\hline Jenis Kelamin & 7 & 8,0 \\
\hline Laki-Laki & 80 & 92,0 \\
Perempuan & & 34,5 \\
\hline Riwayat Keluarga Hipertensi & 30 & 65,5 \\
\hline Ada & 57 & 27,6 \\
Tidak ada & & 72,4 \\
\hline Aktivitas Fisik & 24 & \\
\hline Ringan & 63 & 14,9 \\
Sedang & & 85,1 \\
\hline Stres & 13 & \\
\hline Stres & 74 & 43,7 \\
Tidak Stres & & 56,3 \\
\hline Asupan Lemak & 38 & 31,0 \\
\hline Lebih & 49 & 69,0 \\
Baik & & \\
\hline Asupan Natrium & 27 & \\
\hline Lebih & 60 & \\
Baik & & \\
\hline Asupan Kalium & & \\
\hline Baik & & \\
Kurang & & \\
\hline
\end{tabular}

Berdasarkan hasil penelitian bahwa subyek pada penelitian ini lebih banyak usia early old age (usia 60 sampai 70 tahun) sebanyak 64 responden (73,6\%), sedangkan usia advancedold age (usia $>70$ tahun) sebanyak 23 responden (26,4\%). Untuk distribusi jenis kelamin lebih banyak berjenis kelamin perempuan sebanyak 80 responden $(92,0 \%)$, sedangkan responden yang berjenis kelamin laki-laki sebanyak 7 responden $(8,0 \%)$. Untuk distribusi riwayat keluarga hipertensi lebih banyak responden yang "tidak ada" riwayat keluarga hipertensi sebanyak 57 responden $(34,5 \%)$, sedangkan responden yang "ada" riwayat keluarga hipertensi sebanyak 30 responden $(65,5 \%)$. Untuk distribusi aktivitas fisik lebih banyak aktivitas fisik "sedang" sebanyak 63 responden $(72,4 \%)$, sedangkan responden yang aktivitas fisik "ringan" sebanyak 24 responden
(27,6\%). Berdasarkan distribusi stres lebih banyak yang tidak stres sebanyak 74 responden $(85,1 \%)$, sedangkan yang stres sebanyak 13 responden $(14,9 \%)$. Berdasarkan distribusi asupan lemak lebih banyak memiliki asupan lemak "lebih" sebanyak 38 responden (43,7\%), sedangkan responden yang memiliki asupan lemak "baik" sebanyak 49 responden (56,3\%). Berdasarkan distribusi asupan natrium lebih banyak memiliki asupan natrium "baik" sebanyak 60 responden $(69,0 \%)$, sedangkan responden yang memiliki asupan natrium "lebih" sebanyak 27 responden $(69,0 \%)$. Berdasarkan distribusi asupan kalium lebih banyak memiliki asupan kalium "kurang" sebanyak 86 responden (98,9\%), sedangkan responden yang memiliki asupan kalium "baik" (jika sebanyak 1 responden $(1,1 \%)$. 
Berdasarkan hasil penelitian frekuensi makan dapat dilihat pola atau kebiasaan dan variasi makanan. Menurut Kusharto \& Sutandi dalam Amelia (2010, hlm.47) penggunaan metode frekuensi pangan bertujuan untuk memperoleh data konsumsi pangan secara kualitatif dan informasi deskriptif tentang pola konsumsi. Konsumsi pangan berdasarkan frekuensi dan presentase tertinggi. Konsumsi pangan sumber lemak (daging ayam dengan kulit, daging sapi dan gorengan), sumber natrium (biskuit, roti isi, ikan asin, telur ayam, kecap, bumbu penyedap, vetsin dan garam) dan sumber kalium (bayam, sawi, kol, kembang kol, buncis, dan golongan buah-buahan seperti pisang, jeruk, pepaya).

Tabel 3. Proporsi Kejadian Hipertensi Dengan Variabel Independen di Posbindu Kelurahan Sawangan Baru Kecamatan Sawangan Tahun 2015

\begin{tabular}{|c|c|c|c|c|c|c|c|}
\hline \multirow{3}{*}{ Variabel } & \multicolumn{4}{|c|}{ Tekanan Darah } & \multirow{2}{*}{\multicolumn{2}{|c|}{ Jumlah }} & \multirow{3}{*}{$P$ Value } \\
\hline & \multicolumn{2}{|c|}{ Hipertensi } & \multicolumn{2}{|c|}{$\begin{array}{c}\text { Tidak } \\
\text { Hipertensi }\end{array}$} & & & \\
\hline & $\mathbf{n}$ & $\%$ & $\overline{\mathbf{n}}$ & $\%$ & $\mathbf{n}$ & $\%$ & \\
\hline \multicolumn{8}{|l|}{ Umur } \\
\hline Early old age (usia 60-70 tahun) & 18 & 28,1 & 46 & 71,9 & 64 & 100,0 & 0,749 \\
\hline $\begin{array}{l}\text { Advancedold age (usia }>70 \\
\text { tahun) }\end{array}$ & 5 & 21,7 & 18 & 78,3 & 23 & 100,0 & \\
\hline \multicolumn{8}{|l|}{ Jenis Kelamin } \\
\hline Laki-Laki & 2 & 28,6 & 5 & 71,4 & 7 & 100,0 & 1,000 \\
\hline Perempuan & 21 & 26,3 & 59 & 73,8 & 80 & 100,0 & \\
\hline \multicolumn{8}{|l|}{ Riwayat Keluarga Hipertensi } \\
\hline Ada & 12 & 40,0 & 18 & 60,0 & 30 & 100,0 & 0,068 \\
\hline Tidak ada & 11 & 19,3 & 46 & 80,7 & 57 & 100,0 & \\
\hline \multicolumn{8}{|l|}{ Aktivitas Fisik } \\
\hline Ringan & 11 & 45,8 & 13 & 54,2 & 24 & 100,0 & 0,024 \\
\hline Sedang & 12 & 19,0 & 51 & 81,0 & 63 & 100,0 & \\
\hline \multicolumn{8}{|l|}{ Stres } \\
\hline Stres & 5 & 38,5 & 8 & 61,5 & 13 & 100,0 & 0,468 \\
\hline Tidak Stres & 18 & 24,3 & 56 & 75,7 & 74 & 100,0 & \\
\hline \multicolumn{8}{|l|}{ Asupan Lemak } \\
\hline Lebih & 16 & 42,1 & 22 & 57,9 & 38 & 100,0 & 0,008 \\
\hline Baik & 7 & 14,3 & 42 & 85,7 & 49 & 100,0 & \\
\hline \multicolumn{8}{|l|}{ Asupan Natrium } \\
\hline Lebih & 14 & 51,9 & 13 & 48,1 & 27 & 100,0 & 0,001 \\
\hline Baik & 9 & 15,0 & 51 & 85,0 & 60 & 100,0 & \\
\hline \multicolumn{8}{|l|}{ Asupan Kalium } \\
\hline Baik & 1 & 100,0 & 0 & 0,0 & 1 & 100,0 & 0,264 \\
\hline Kurang & 22 & 25,6 & 64 & 63,6 & 86 & 100,0 & \\
\hline
\end{tabular}

\section{Usia}

Berdasarkan hasil uji chi square antara usia dengan kejadian hipertensi didapatkan tidak ada hubungan yang signifikan antara usia dengan kejadian hipertensi $(\mathrm{p}=0,749)$. Hasil penelitian ini tidak sesuai dengan pernyataan Junaedi dkk. (2013) yang mengatakan prevalensi hipertensi meningkat seiring dengan bertambahnya usia Hal ini disebabkan karena perubahan alami pada jantung, pembuluh darah, dan kadar hormon 
dapat meningkatkan tekanan darah seiring dengan bertambahnya usia.

Meskipun secara statistik tidak ditemukan hubungan yang bermakna antara usia dengan hipertensi namun dapat di lihat kecenderungan prevalensi hipertensi pada usia early old age sebesar 28,1\% yang menderita hipertensi lebih besar dibandingkan usia advancedold age sebesar 21,7\%. Hal tersebut sejalan dengan penelitian yang dilakukan oleh (Pratiwi \& Tala, 2013) di Poli RSUP H.Adam Malik Medan hipertensi lebih banyak pada usia 60 - 74 tahun dibandingkan usia $75-90$ tahun.

\section{Jenis Kelamin}

Berdasarkan hasil uji chi square antara jenis kelamin dengan kejadian hipertensi didapatkan tidak ada hubungan yang signifikan antara jenis kelamin dengan kejadian hipertensi $(p=1,000)$. Hasil penelitian ini tidak sesuai dengan pernyataan Prasetyaningrum (2014) yang mengatakan laki-laki lebih beresiko mengalami hipertensi dibandingkan perempuan saat usia $<45$ tahun. Tetapi saat usia $>65$ tahun, perempuan lebih beresiko mengalami hipertensi dibanding lakilaki setelah wanita memasuki masa monopouse prevalensi pada wanita akan semakin meningkat dikarenakan faktor hormonal.

Meskipun secara statistik tidak ditemukan hubungan yang bermakna antara jenis kelamin dengan hipertensi namun dapat di lihat kecenderungan prevalensi hipertensi laki-laki sebesar 28,6\% yang menderita hipertensi lebih besar dibandingkan perempuan 26,3\%. Hal tersebut sejalan dengan penelitian yang dilakukan oleh Susyani dkk. (2012) hasil menunjukkan bahwa tidak ada hubungan yang bermakna antara jenis kelamin dengan kejadian hipertensi dimana p-value $=0,404$. Berbeda dengan hasil Riset Kesehatan Dasar (2013) menunjukkan prevalensi hipertensi pada perempuan cenderung lebih tinggi dibanding laki-laki.

\section{Riwayat Keluarga Hipertensi}

Berdasarkan hasil uji chi square antara riwayat keluarga hipertensi dengan kejadian hipertensi didapatkan tidak ada hubungan yang signifikan antara riwayat keluarga hipertensi dengan kejadian hipertensi $(p=0,068)$. Hasil penelitian ini tidak sesuai dengan pernyataan
Sutanto (2010) yang mengatakan sebagian besar kasus hipertensi dipengaruhi oleh faktor keturunan. Jika kedua orang tua memiliki riwayat penyakit hipertensi anaknya akan beresiko terkena hipertensi, terutama pada hipertensi primer (essensial). Hal ini terjadi karena adanya gen yang berhubungan dengan kejadian hipertensi yang menurun pada dirinya.

Meskipun secara statistik tidak ditemukan hubungan yang bermakna antara riwayat keluarga hipertensi dengan kejadian hipertensi namun, dapat di lihat kecenderungan prevalensi hipertensi yang ada riwayat keluarga hipertensi sebesar $40,0 \%$ yang menderita hipertensi lebih besar dibandingkan yang tidak ada riwayat keluarga hipertensi sebesar 19,3\%. Penelitian yang dilakukan oleh Adiningsih (2012) juga menunjukkan hal yang sama yaitu tidak ada hubungan yang bermakna antara keturunan dengan hipertensi.

Berbeda dengan hasil penelitian yang dilakukan oleh Mannan dkk. (2012) mengatakan bahwa seseorang akan memiliki kemungkinan lebih besar untuk mendapatkan hipertensi jika kedua orang tuanya menderita hipertensi. Seseorang yang memiliki riwayat keluarga hipertensi beresiko 4,36 kali.

\section{Aktivitas Fisik}

Berdasarkan hasil uji chi square antara aktivitas fisik dengan kejadian hipertensi didapatkan tidak ada hubungan yang signifikan antara aktivitas fisik dengan kejadian hipertensi $(p=0,024)$. Hal ini menunjukkan bahwa sebagian besar responden memiliki intensitas aktifitas fisik yang sedang. Hal ini kemungkinan karena sebagian besar responden telah berusia lanjut, sehingga sudah tidak mampu melakukan aktifitas fisik yang berat. Selain itu, sebagian besar responden adalah ibu rumah tangga, yang digantikan oleh anak mereka untuk melakukan perkejaannya. Hasil penelitian sejalan dengan pernyataan Junaedi dkk. (2013) mengatakan bahwa seseorang yang tidak aktif memiliki frekuensi denyut jantung lebih tinggi sehingga otot jantung harus bekerja lebih keras pada saat kontraksi sehingga menyebabkan kenaikan tekanan darah.

Penelitian ini sejalan dengan penelitian terkait yang dilakukan oleh Muliyati dkk. (2011) hasil penelitian ini menunjukkan bahwa ada hubungan antara aktifitas fisik dengan 
kejadian hipertensi, sebanyak 64,4\% responden yang memiliki aktivitas fisik ringan menderita hipertensi, sedangkan $100 \%$ responden yang beraktifitas fisik sedang tidak hipertensi.

Berbeda dengan hasil penelitian ini, penelitian yang dilakukan oleh Sudartinah (2012) yang menyatakan bahwa tidak ada hubungan yang bermakna antara aktivitas fisik dengan kejadian hipertensi. Namun walaupun tidak terdapat hubungan namun didapatkan hasil responden yang memiliki aktivitas ringan beresiko 1,843 untuk terkena hipertensi dibandingkan dengan responden yang memiliki aktivitas fisik yang tinggi.

\section{Stres}

Berdasarkan hasil uji chi square antara stres dengan kejadian hipertensi didapatkan tidak ada hubungan yang signifikan antara stres dengan kejadian hipertensi $(p=0,468)$. Hasil penelitian ini tidak sesuai dengan pernyataan Wijayaningsih (2014) Stres akan meningkatkan resistensi pembuluh darah perifer dan curah jantung yang menstimulasi aktivitas saraf simpatis untuk pengeluarkan hormon adrenalin yang menyebabkan jantung berdenyut lebih cepat dan menyebabkan penyempitan pembuluh darah perifer yang dapat mengakibatkan terjadinya peningkatan tekanan darah (Ramayulis, 2010).

Meskipun secara statistik tidak ditemukan hubungan yang bermakna antara stres dengan kejadian hipertensi namun dapat di lihat kecenderungan prevalensi hipertensi yang stres sebesar 38,5\% yang menderita hipertensi lebih besar dibandingkan yang tidak stres sebesar $23,4 \%$. Penelitian yang dilakukan oleh Stefhany (2012) menyatakan tidak ada hubungan yang bermakna antara stres dengan kejadian hipertensi. Karena besaran sampel yang tidak mencukupi untuk menunjukkan kebermaknaan.

Berbeda dengan hasil Penelitian ini, penelitian yang dilakukan oleh Sount dkk. (2014) yang menyatakan bahwa ada hubungan yang bermakna antara stres dengan kejadian hipertensi di Puskesmas Kolongan Kecamatan Kalawat. Begitupun pada penelitian yang dilakukan oleh Anggraini dkk. (2009) menemukan adanya hubungan yang bermakna antara stres yang dilakukan dengan cara melihat tipe kepribadian dengan hipertensi.

\section{Asupan Lemak}

Berdasarkan hasil uji chi square antara asupan lemak dengan kejadian hipertensi didapatkan tidak ada hubungan yang signifikan antara asupan lemak dengan kejadian hipertensi $(\mathrm{p}=0,008)$. Hasil penelitian ini sesuai dengan pernyataan Ramayulis (2010) yang mengatakan pola makan yang salah dapat menyebabkan peningkatan tekanan darah seperti kebiasaan mengkonsumsi makanan berlemak terutama pada asupan lemak jenuh dan kolesterol.

Penelitian ini sejalan dengan penelitian terkait yang dilakukan oleh Sangadji \& Nurhayati (2014) menunjukkan bahwa proporsi kejadian hipertensi lebih tinggi pada responden yang sering mengkonsumsi lemak lebih besar dibandingkan responden yang jarang mengkonsumsi lemak. Berbeda dengan hasil Penelitian ini, penelitian yang dilakukan oleh Adiningsih (2012) menunjukkan bahwa tidak ada hubungan antara konsumsi lemak dengan kejadian hipertensi.

\section{Asupan Natrium}

Berdasarkan hasil uji chi square antara asupan natrium dengan kejadian hipertensi didapatkan tidak ada hubungan yang signifikan antara asupan natrium dengan kejadian hipertensi $(p=0,001)$. Hasil penelitian ini sesuai dengan pernyataan Susanto (2010) konsumsi natrium yang berlebih akan meningkatkan ekstraseluler dan cara untuk menormalkannya cairan intraseluler ditarik keluar sehingga volume cairan ekstraseluler meningkat dan akibat dari meningkatnya volume cairan ekstraseluler tersebut menyebabkan meningkatnya volume darah yang berdampak pada timbulnya hipertensi.

Penelitian ini sejalan dengan penelitian terkait yang dilakukan oleh Mamoto dkk. (2012) hasilnya menunjukkan terdapat hubungan yang bermakna antara asupan natrium dengan kejadian hipertensi. Berbeda dengan penelitian yang dilakukan oleh Maria, dkk. (2012) hasil penelitian menunjukkan tidak terdapat hubungan antara asupan natrium dengan hipertensi, hasilnya menunjukkan nilai $\mathrm{p}=0,625(>0,05)$.

Penelitian yang dilakukan oleh (Indrawati dkk. (2009) yang menemukan hubungan yang bermakna antara konsumsi makanan asin, mengandung sodium glutamat (vetsin, kecap dan saus) dengan kejadian hipertensi. 


\section{Asupan Kalium}

Berdasarkan hasil uji chi square antara asupan kalium dengan kejadian hipertensi didapatkan tidak ada hubungan yang signifikan antara asupan kalium dengan kejadian hipertensi $(p=0,264)$. Hasil penelitian ini tidak sesuai dengan pernyataan AS (2010) yang mengatakan jika asupan kalium tercukupi maka akan membuat perubahan positif tekanan darah pada penderita hipertensi. Tetapi jika kurang mengkonsumsi sumber makanan yang mengandung kalium mengakibatkan jumlah natrium menumpuk dan akan meningkatkan resiko terjadinya hipertensi.
Penelitian ini sejalan dengan penelitian terkait yang dilakukan oleh Maria dkk (2012) hasil penelitian menunjukkan tidak terdapat hubungan antara asupan kalium dengan hipertensi, hasilnya menunjukkan nilai $\mathrm{p}=0,474(>0,05)$ hal ini disebabkan karena sedikitnya jumlah konsumsi sayuran dan buah-buahan sumber kalium. Berbeda dengan hasil Penelitian ini, penelitian yang dilakukan oleh Annisa (2009) hasil penelitian menunjukkan ada hubungan antara asupan kalium dengan hipertensi.

Tabel 4. Hasil Analisis Regresi Logistik Terhadap Faktor-Faktor Yang Mempengaruhi Kejadian Hipertensi Di Posbindu Kelurahan Sawangan Baru Kecamatan Sawangan Tahun 2015

\begin{tabular}{|c|c|c|c|c|c|c|c|c|}
\hline \multirow[t]{2}{*}{ Variabel } & \multirow[t]{2}{*}{ B } & \multirow[t]{2}{*}{ S.E } & \multirow[t]{2}{*}{ Wald } & \multirow[t]{2}{*}{ df } & \multirow[t]{2}{*}{ Sig. } & \multirow[t]{2}{*}{$\operatorname{Exp}(B)$} & \multicolumn{2}{|c|}{$\begin{array}{c}\text { 95\% C.I.for } \\
\text { EXP (B) }\end{array}$} \\
\hline & & & & & & & Lower & Upper \\
\hline Asupan Lemak & 1,118 & 0,559 & 4,006 & 1 & 0,045 & 3,060 & 1,024 & 9,149 \\
\hline Asupan Natrium & 1,532 & 0,551 & 7,731 & 1 & 0,005 & 4,629 & 1,572 & 13,635 \\
\hline
\end{tabular}

Hasil penelitian ini menunjukkan bahwa hasil analisis regresi logistik berganda terlihat nilai OR Exp (B) asupan natrium sebesar 4,627 dapat diartikan bahwa responden yang asupan natrium berlebih memiliki resiko 4,627 kali lebih besar untuk mengalami kejadian hipertensi dibandingkan responden yang asupan natriumnya baik (OR Exp (B) $=4,627 ; 95 \%$ CI $=1,574$ 13,635). Dalam hasil ini asupan natrium yang paling besar pengaruhnya terhadap kejadian hipertensi.Natrium merupakan kation utama dalam cairan ekstraseluler. $35-40 \%$ natrium ada didalam kerangka tubuh (Almatsier, 2009). Asupan natrium berlebih terutama dalam bentuk natrium klorida dapat menyebabkan gangguan keseimbangan cairan tubuh yang menyebabkan adema dan hipertensi. Natrium yang tinggi juga dapat mengecilkan diameter pembuluh darah arteri sehingga jantung memompa darah lebih kuat. Selain pembatasan natrium yang terdapat dalam garam dapur, perlu dibatasi natrium yang terdapat dalam soda kue, baking powder, natrium benzoat, dan vetsin (Ramayulis, 2010).

Penelitian ini sejalan dengan penelitian yang dilakukan oleh Muliyati dkk. (2011) hasil penelitian menggunakan analisi regresi logistik menunjukkan bahwa resiko untuk menderita hipertesi bagi subyek yang mengkonsumsi natrium dalam jumlah yang tinggi memiliki resiko 5,6 kali lebih besar dibangingkan dengan yang mengkonsumsi natrium dalam jumlah yang rendah. Dan penelitian yang dilakukan oleh Hermawan \& Sulchan (2007) menunjukkan asupan natrium merupakan faktor resiko paling kuat $\mathrm{OR}=7,389$ terhadap kejadian hipertensi.

Penelitian ini tidak sejalan dengan penelitian yang dilakukan oleh Fitriawan dkk. (2014) hasilnya membuktikan bahwa olahraga merupakan satusatunya faktor yang mempengaruhi terjadinya penyakit tidak menular (PTM) seperti hipertensi dan diabetes melitus) pada warga penduduk Jogad dengan p-value $=0,048$.

\section{SIMPULAN}

Hasil penelitian menujukkan ada hubungan yang signifikan antara aktivitas fisik, asupan lemak, dan asupan natrium dengan kejadian hipertensi. Berdasarkan hasil regresi logistik berganda asupan natrium yang paling berhubungan dengan kejadian hipertensi yang memiliki resiko 4,627 kali lebih besar untuk mengalami kejadian hipertensi (OR $\operatorname{Exp}(B)=4,627 ; 95 \% C I=1,574-13,635)$. 


\section{DAFTAR PUSTAKA}

Adiningsih, ER 2012, Hubungan status gizi, asupan makan, karakteristik, responden dan gaya hidup dengan kejadian hipertensi pada guru-guru sman di kota tanggerang tahun 2012, Skripsi Pasca Sarjana, Universitas Indonesia Depok.

Almatsier, S 2009, Prinsip dasar ilmu gizi, PT. Gramedia Pustaka Utama, Jakarta

Amelia, F 2008 Konsumsi pangan, pengetahuan gizi, aktivitas fisik dan status gizi pada remaja dikota sungai penuh kabupaten kerinci propinsi jambi. Skripsi Pasca Sarjana, Institut pertanian bogor.

Anggraini, AD, Waren, A, Situmorang, E, Asputra, H, Siahaan, SS 2009, 'Faktorfaktor yang berhubungan dengan kejadian hipertensi pada pasien yang berobat di poliklinik dewasa puskesmas Bangkinang periode januari sampai juni 2008', Files of DrsMed_FK UNRI, Juni 2008, hlm.1-41.

Annisa 2009, 'Hubungan antara asupan natrium, kalium, kalsium dengan hipertensi di Puskesmas merbangsan Yogyakarta', Universitas Gadjah Mada.

AS, M 2010, Hidup bersama hipertensi, In Book, Yogyakarta

Azizah, LM 2011, Keperawatan lanjut usia, Graha Ilmu, Jakarta

Fitriawan, AS, Hasan, R, Achmad, BF 2014 'Faktor-faktor yang mempengaruhi kejadian penyakit tidak menular (hipertensi dan diabetes mellitus) dipadukuhan jogad, kabupaten sleman yogyakarta', BIMIKI, vol.2, no.2, Januari-Juni 2014, hlm.1-13.

Hartono, A 2013, Edisi 2 terapi gizi dan diet rumah sakit, Penerbit Buku Kedokteran EGC, Jakarta

Hermawan, EN, Sulchan, M 2007, Faktor determinan gizi kejadian hipertensi. Skripsi Universitas Dipomegoro, Skripsi Pasca Sarjana, Fakultas Kedokteran Universitas Diponerogo

Indonesia, Undang-Undang Republik Indonesia 1998, tetang Kesejahteraan Lanjut Usia. Jakarta.
Indrawati, L, Werdhasari, A, Yudi, A 2009, 'Hubungan pola kebiasaan konsumsi makanan masyarakat miskin dengan kejadian hipertensi di Indonesia', Media Peneliti dan Pengembangan Kesehatan. vol. XIX no.4 Tahun 2009.

Junaedi E, Yulianti, S, Rinata, MG 2013, Hipertensi kandas berkat herbal, Fmedia (Imprint AgroMedia Pustaka), diaskes 04 Maret 2015.

Krishnan, A, Garg, R, Kahadaliyanage, A 2013, 'Hypertension in the sount-east asian region : an overview', Regional Health Forum-vol.17, no.1, hlm.7-14.

Mamoto, F, Kandou, GC, Pijoh, VD 2012, 'Hubungan antara asupan natrium dan obesitas dengan kejadian hipertensi pada pasien poliklinik umum di puskesmas Tumaratas kecamatan Langowan Kabupaten Minahasa, hlm.1-6.

Mannan, H, Wahiduddin, Rismayanti 2012 'Faktor resiko kejadian hipertensi di wilayah kerja puskesmas bangkala kabupaten jeneponto tahun 2012', hlm.1-13.

Maria, G, Puspita, RT, Sulistyowati, Y 2012, 'Hubungan asupan natrium dan kalium dengan tekanan darah pada pasien hipertensi di unit Rawat jalan di rumah sakit guido valadares dili timor leste', hlm.1-15.

Muliyati, H, Syam, A, Sirajuddin, S 2011, 'Hubungan pola konsumsi natrium dan kalium serta aktifitas fisik dengan kejadian hipertensi pada pasien rawat jalan di RSUP DR.Wahidin Sudirohusodo Makassar', Media Gizi Masyarakat Indonesia, vol.1, no.1, Agustus 2011, hlm.46-51.

Nurrahmani, U 2011, Stop hipertensi, Familia, Yogyakarta

Prasetyaningrum, YI 2014, Hipertensi bukan untuk ditakuti, Fmedia (Imprint AgroMedia Pustaka), Jakarta

Pratiwi, VR dan Tala, ZZ 2013. 'Gambaran status gizi pasien hipertensi lansia di rsup $h$. adam malik medan' e-Jurnal FK USU, vol.1(1):15.

Ramayulis, R 2010, Menu dan resep untuk penderita hipertensi, Penebar Plus ${ }^{+}$, Jakarta 
Riset Kesehatan Dasar (Riskesdas) 2013.

Sangadji, NW \& Nurhayati 2014 'Hipertensi Pada Pramusaji Bus Transjakarta Di Pt.Bianglala Metropolitan Tahun 2013' BIMKMI, Vol.2 no.2, Januari-Juni 2014, hlm.1-10.

Suoth, M, Bidjuni, H, Malara, RT 2014 'Hubungan gaya hidup dengan kejadian hipertensi di puskesmas kolongan kecamatan kaawat kabupaten minahasa utara 2014', Jurnal Keparawatan (e-Kp), vol.2, no.1, Februari 2014, hlm.1-10.

Stefhany, E 2012, Hubungan pola makan, gaya hidup, dan indeks massa tubuh dengan hipertensi pada pra lansia dan lansia di posbindu kelurahan depok jaya tahun 2012, Skripsi Paska Sarjana, Universitas Indonesia Depok
Sunardi, Y 2012, Sehat itu pilihan gaya hidup sehat tanpa repot, ANDI, Yogyakarta

Susyani, Rotua, M, Suryani,E2012, 'Polakonsumsi makanan olahan dan kejadian hipertensi di rumah sakit umum daerah Prabumulih Tahun 2012', Jurnal Pembagunan Manusia, vol.7, no.1 April 2013, hlm.11-19.

Sutanto 2010, Cekal (cegah \& tangkal) penyakit modern, ANDI, Yogyakarta 